\title{
Analysis of Spatial-Temporal Changes of Agricultural Land Use During the Last Three Decades in the Araban District of Turkey Using Remote Sensing
}

\begin{abstract}
Agricultural land use and land cover dynamics were investigated in the Araban district of Turkey during the periods 1984-2019 by the use of Remote Sensing and Geographic Information Systems (GIS). Land sat-TM and Landsat-TIRS / OLI satellite imageries were used to determine land use and land cover changes. Using unsupervised classification method of ERDAS 8.3 software, three main agricultural activities were identified namely irrigated farming, dry farming, and horticultural / garden farming. The analysis has revealed that during the last three decades dry farming has decreased significantly by $14.69 \%$ ( 3802.14 ha) whereas horticultural/garden crops and irrigated farming lands have increased by $11.32 \%$ ( $667.19 \mathrm{ha}$ ) and $2.51 \%$ (2929.41 ha) respectively. Araban has been under intensive agricultural use due to its fertile soil and preference for horticultural crops such as pistachio, grapes and olives that provide more profit over dry farming crops such as wheat and barley has changed land use. Decrease in dry farming in a semi-arid climate where Araban is located, has a potential ecological consequence, including a rapid drop of groundwater level, drying of wetlands and the disappearance of the biodiversity, thus, a necessary measures should be taken to implement an environmentally friendly, sustainable agriculture and settlement plan.
\end{abstract}

Keywords: agricultural land use, spatial temporal change, Araban, remote sensing, Landsat

Received: 1 July 2020; accepted: 3 September 2020

(C) 2021 Authors. This is an open access publication, which can be used, distributed and reproduced in any medium according to the Creative Commons CC-BY 4.0 License.

1 Gaziantep University, Biology Department, Gaziantep, Turkey, email: tunc@gantep.edu.tr, ORCID ID: https://orcid.org/0000-0001-9861-6855

2 Independent researcher, 1696 Ball Avenue. Northeast, Grand Rapids, Michigan, 49505, USA, email: teawete@gmail.com, ORCID ID: https://orcid.org/0000-0003-3300-836X

3 Gaziantep University, Biology Department, Gaziantep, Turkey, email: N/A, ORCID ID: https://orcid.org/0000-0002-3158-4921 


\section{Introduction}

According to the United Nations (UN) Food and Agriculture Organization (FAO), it is estimated that more than 800 million people in the world suffer from chronic hunger [1]. Lack of enough agricultural land is one of the most important reasons for 1 billion people in the world (and in these geographical areas in particular) suffering from chronic hunger [2]. In this context, sustainable management of agricultural lands and fertile soil is of great importance. Accurate and planned management of agricultural areas is also of great importance in a socio-economic sense. At the same time, it is imperative to monitor agricultural land in order to meet the nutritional needs of the world population, which is growing rapidly and is now over 8 billion [3].

The spatial and temporal patterns of a region are the result of both natural and anthropological factors [4, 5]. Spatial and temporal distribution of land use is one of the key components in detecting the extent of human influence on natural environment. In most cases, the change in land use is due to different anthropogenic activities e.g. human settlement, agricultural expansion, forest logging, commercial plantation, mining, industry, and road building, etc. [6-9]. Thus, any land-use change has a substantial impact on the world's ecosystems and socioeconomic condition at local, regional and global levels $[10,11]$. Therefore, land use information is essential to effectively manage both the environment and human living conditions.

Remote sensing methodology is often used to monitor current changes in agricultural land within a short period of time $[12,13]$. In recent years, data from remote sensing satellites have been widely used in a range of applications for selection, planning and implementation of schemes by planners, resource managers, scientists and decision makers from state, regional, local government and private corporations [14-17]. With remote sensing, agricultural fields can be monitored with a high degree of accuracy, in a shorter time and with less labor. As a result, many countries in the world benefit from the use of remote sensing methodology for the management and planning of agricultural land.

Topics on remote sensing and agricultural land use have frequently drawn great attention for researchers starting from Europe to China and US [18-20]. Araban, a district located northeast of Gaziantep, Turkey, has been under intensive agricultural use due to its fertile soil [21-23]. The city was founded on a colluvial plain and the main source of income is agricultural activities. In this study we investigated agricultural land use in the Araban district between 1984 and 2019 using remote sensing data.

\section{Methods and Materials}

\subsection{The Study Site}

Araban is a district located to the northeast of the Turkish city of Gaziantep. Araban has a surface area of 25,884.54 ha and is bordered by the Besni district of Adiyaman 
to the north, Pazarcık district of Kahramanmaraş to the west, Halfeti district of Şanliurfa to the east and Yavuzeli district to the south. The average elevation of Araban is around $600 \mathrm{~m}$ but its highest point exceeds $1000 \mathrm{~m}$. In the valleys at the bottom of the plain, the altitude falls to $370 \mathrm{~m}$. The flat areas located on the bottom of the plain and the low elevation areas are the most important for land use. The Araban district is surrounded by the Euphrates River to the east, the Sof Mountains in the west, the Beştepe Mountains to the north and Karadağ in the south (Fig. 1). The Euphrates River in the East and Karasu Stream in the West are the most important water resources in the district. These rivers break apart the new Holocene alluvium units at the bottom of the plain. The part with the Beştepe Mountains in the north is middle Eocene, while the mountainous mass in the south is from the lower Eocene. In the part where there are Sof Mountains in the southwest, basalt units are visible in the area.

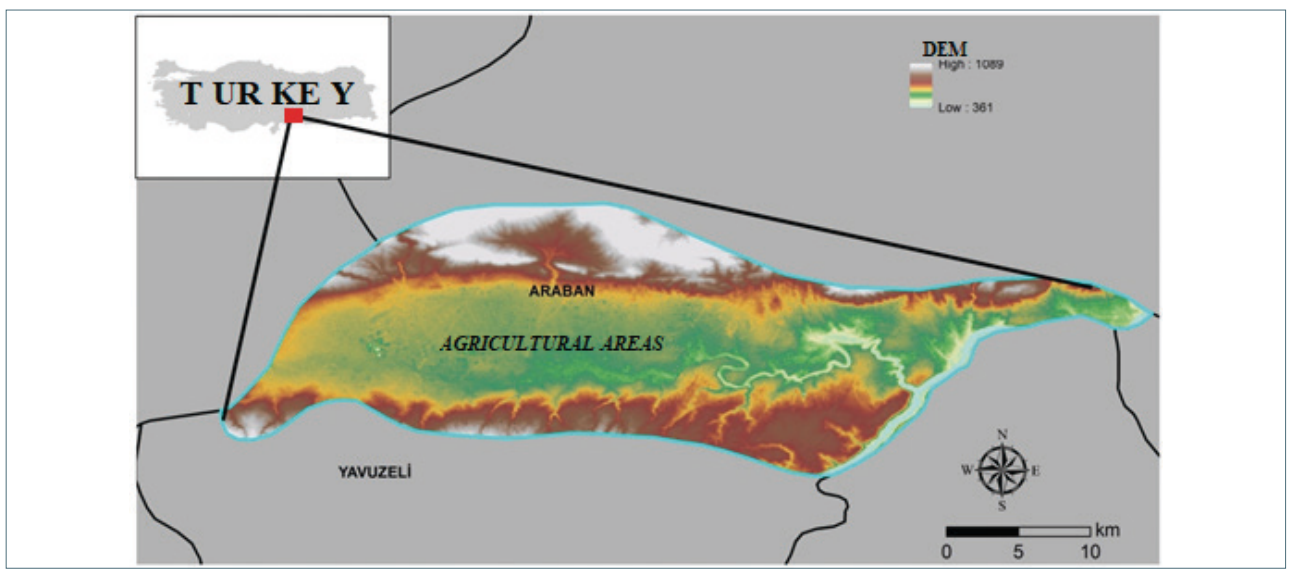

Fig. 1. Study area location map

The Araban district generally boasts a warm and temperate climate (Fig. 2). According to the Koppen-Geiger climate classification method [24], the climate type symbolized as "Csa" is dominant in Araban. "Csa" climate is warm and dry Mediterranean climate with warm and dry winters. According to the (1984-2019) TerraClimate data, precipitation in the study area is quite high in the winter months while in the summer it is very low (Fig. 2). Annual total precipitation in the study area is $521 \mathrm{~mm}$. July is the driest period of the year with $2 \mathrm{~mm}$ of rainfall. December is wettest year with $99 \mathrm{~mm}$ rainfall. The average annual temperature of Araban is $16.9^{\circ} \mathrm{C}$. July and January are the hottest and coldest months of the year with an average temperature of $29.6^{\circ} \mathrm{C}$ and $4.6^{\circ} \mathrm{C}$ respectively. The difference in precipitation between the driest and the wettest period of the year is $100 \mathrm{~mm}$. The mean annual temperature has increased significantly over the past three decades (Fig. 3). The mean annual precipitation however, remained relatively the same with a slight increase (Fig. 4). 


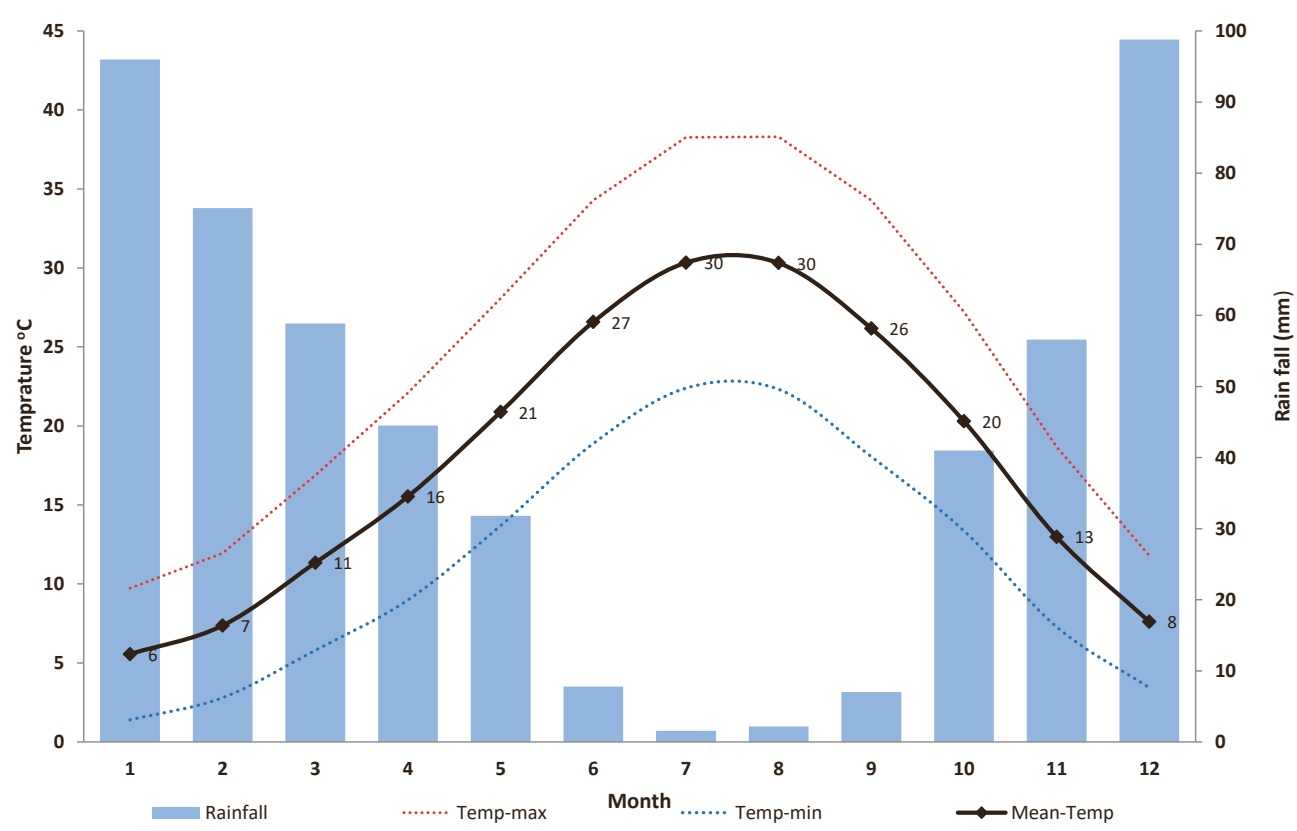

Fig. 2. Average monthly temperature and precipitation diagram of the Araban district 1984-2019 Source: TerraClimate database (http://www.climatologylab.org/terraclimate.html)

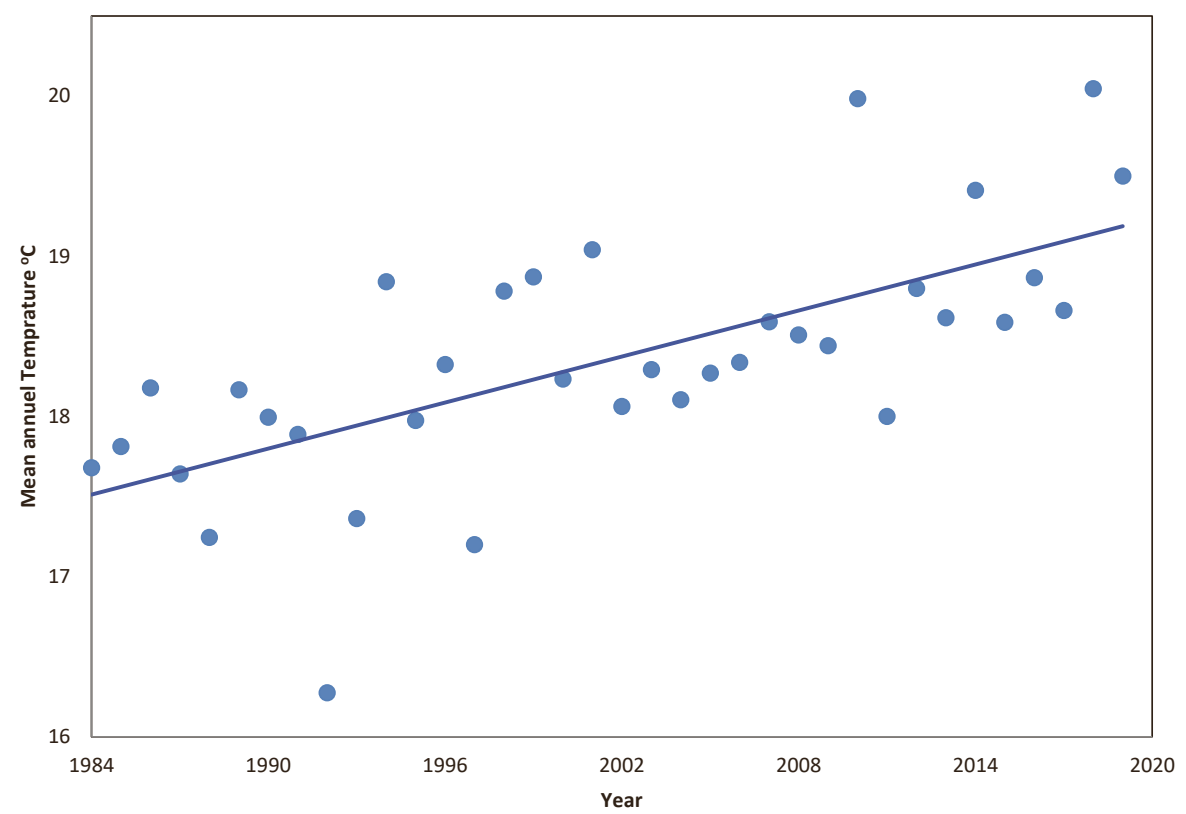

Fig. 3. Mean annual temperature of the Araban district 1984-2019

Source: TerraClimate database (http://www.climatologylab.org/terraclimate.html) 


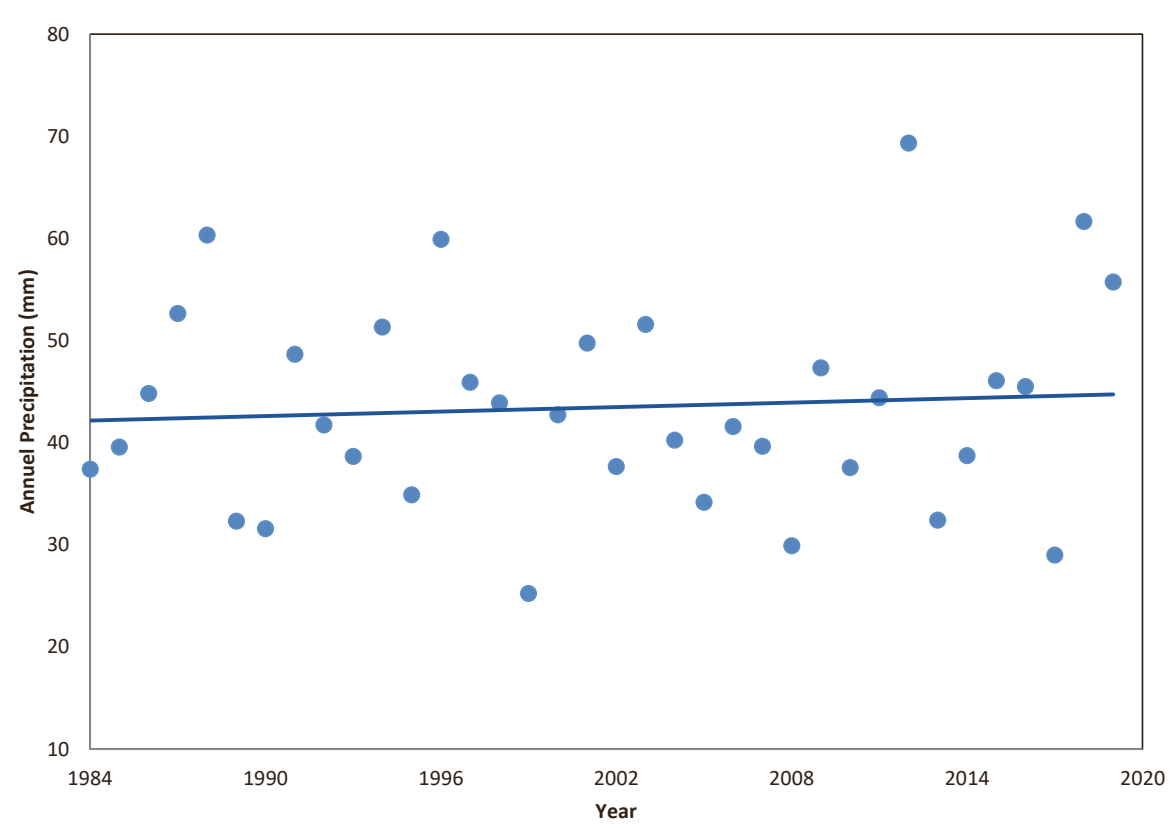

Fig. 4. Mean annual precipitation of the Araban district 1984-2019

Source: TerraClimate database (http://www.climatologylab.org/terraclimate.html)

\subsection{The Data}

In this study, Landsat satellite data of agricultural fields from the past 35 years (1984-2019) was used. Landsat has been relaying data from space since 1972 and the Landsat satellite data has been used in many studies [25-28]. The data used for our research was from the summer months, since these give the chance to classify with a higher degree of accuracy due to the low cloudiness.

In our study, Landsat TM and Landsat TIRS / OLI satellite images of June of 1984, 2000 and 2019 were used (Tab. 1).

Table 1. Satellite data used in the study

\begin{tabular}{|l|c|}
\hline \multicolumn{1}{|c|}{ Sensor } & Year \\
\hline Landsat TM & 27.06 .1984 \\
\hline Landsat TM & 30.06 .2000 \\
\hline Landsat OLI/TIRS & 03.06 .2019 \\
\hline
\end{tabular}

To compute the land use classification, an unsupervised classification method was applied to Landsat satellite images with a combination of 4, 3 and 2 bands in the ERDAS Imagine 8.5 Software. First, 100 classes were created, and then these classes were reduced to 5 main classes through recode (Fig. 6). These classes are identified as irrigated farming, dry farming, vineyard / garden farming, pasture 
and settlement. ISODATA algorithm was used in unsupervised classification. Unsupervised classification was based on the automatic detection of similar pixels and are assigned to classes depending on the color/spectral values in the satellite image.

At the last stage, accuracy analyzes were performed according to the kappa statistical method on the data produced by the unsupervised classification technique. The kappa coefficient for statistical analysis was obtained by using the rows and column sums of the error matrix and its diagonal elements [29]. The kappa value ranges from 0 to 1 and measures the accuracy of image classification. GIS and image processing, classification and accuracy analysis were carried out with ERDAS Imagine 8.5 software.

\section{Results and Discussion}

Agricultural land use map was generated from Landsat TM satellite data of 1984 with $82 \%$ accuracy according to the kappa statistical method. A higher accuracy was obtained from 1990 Landsat TM satellite data. That is, according to the kappa statistical analysis, the agricultural land use map of 1990 has an accuracy of $90 \%$. Agricultural land use map produced from Landsat OLI / TIRS satellite data for 2019 was with $87 \%$ accuracy according to the kappa statistical analysis (Tab. 2).

Table 2. The accuracy analysis of the maps obtained by the unsupervised classification technique

\begin{tabular}{|c|c|c|c|c|c|}
\hline & Irrigation farm & Dry farm & Horticulture crop & Total & User error [\%] \\
\hline Irrigation farm & 8 & 0 & 0 & 3 & 0.00 \\
\hline Dry farm & 2 & 51 & 3 & 55 & 0.07 \\
\hline Horticulture crop & 0 & 5 & 31 & 36 & 0.13 \\
\hline Total & 10 & 56 & 34 & 100 & - \\
\hline \multirow[t]{3}{*}{ Producer error [\%] } & 0.25 & 0.12 & 0.08 & - & 0.11 \\
\hline & \multicolumn{5}{|c|}{1984 Error matrix general accuracy $90 \%$, kappa $82 \%$} \\
\hline & Irrigation farm & Dry farm & Horticulture crop & Total & User error [\%] \\
\hline Irrigation farm & 15 & 0 & 0 & 18 & 0.00 \\
\hline Dry farm & 7 & 33 & 6 & 40 & 0.17 \\
\hline Horticulture crop & 8 & 3 & 38 & 41 & 0.07 \\
\hline Total & 30 & 36 & 44 & 100 & - \\
\hline \multirow[t]{3}{*}{ Producer error [\%] } & 0.05 & 0.08 & 0.13 & - & 0.10 \\
\hline & \multicolumn{5}{|c|}{2000 Error matrix overall accuracy $91 \%$, kappa $85 \%$} \\
\hline & Irrigation farm & Dry farm & Horticulture crop & Total & User error [\%] \\
\hline Irrigation farm & 25 & 0 & 0 & 25 & 0.00 \\
\hline Dry farm & 3 & 29 & 3 & 32 & 0.09 \\
\hline Horticulture crop & 5 & 1 & 33 & 34 & 0.02 \\
\hline Total & 33 & 31 & 36 & 100 & - \\
\hline \multirow[t]{2}{*}{ Producer error [\%] } & 0.07 & 0.06 & 0.10 & - & 0.08 \\
\hline & \multicolumn{5}{|c|}{2019 Error matrix overall accuracy 93\%, kappa $87 \%$} \\
\hline
\end{tabular}


The economic activities of the Araban district vary greatly depending on the landforms. Agriculture is the most important economic activity in the Araban district. Besides irrigated agricultural crops such as cotton and corn, dry farming products such as wheat and barley are the main vegetable products. In addition, garlic is an important constituent of agricultural products. The most common agricultural activity in Araban District in the recent years is horticulture / garden agriculture and pistachio cultivation takes the largest part.

When the agricultural crop pattern is examined in the Araban district, we generally find three types of agricultural activities. The horticulture / garden activity covers the majority of the area with agricultural products such as pistachio, olive and grape predominating. The second type of agricultural activity that covers the most area in the district is irrigated agriculture. Dry farming areas, however, have been decreasing continuously in the last 35 years since 1984 . The reason for this is the preference of agricultural crops such as irrigated agriculture or horticulture / garden crops with higher profits. While irrigated agricultural products increased between 1984 and 2000, these products have recently been replaced by high-income products such as pistachio (Fig. 5).

a)

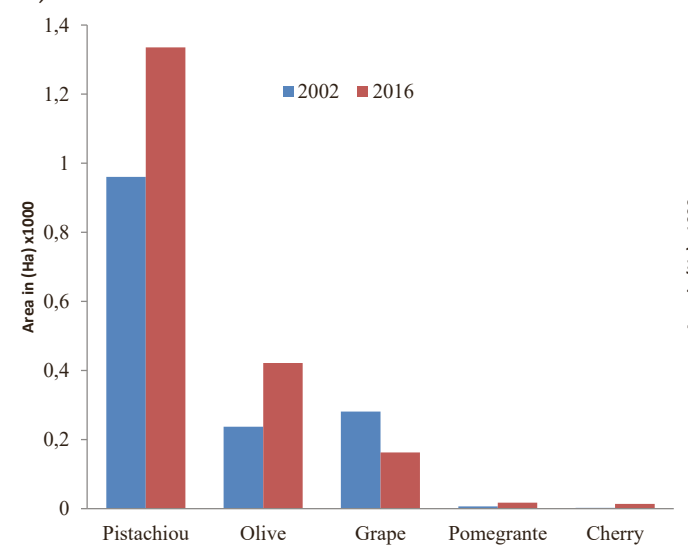

b)

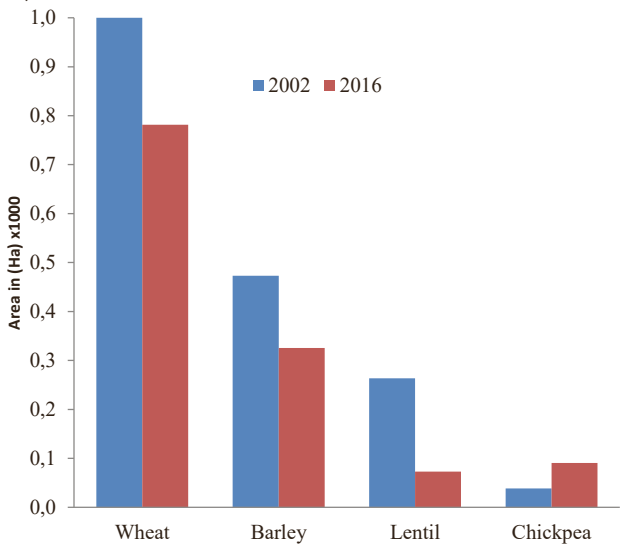

Fig. 5. Comparison of common agricultural crops in Gaziantep province: a) horticultural/garden crops; b) dry farming in the years 2002 and 2016 Source: [30]

In the study area, as of 2019, the agricultural areas that covers the most area is horticultural / garden crops. That is, it covers an area of 8861 ha of the Araban district and this corresponds to approximately $34 \%$ of the district's surface area. In the years 2000 and 1984 this area covered 30\% and 22\% of the Araban district respectively (Fig. 6). The result shows horticultural / garden cultivation has been increasing continuously in the last 35 years. On the other hand, dry farming areas have been reducing continuously in the last 35 years. The dry farming area, which 
was over 11,000 ha in 1984 , is around 7,000 ha in 2019 . As of 2019 , the dry farming in the study area covers an area of approximately $27 \%$, this was $42 \%$ in 1984 , a decrease of 3,800 ha in the last 35 years (Tab. 3). These areas were largely replaced by horticultural / garden cultivation. Horticultural / garden agricultural area has increased by 2,900 ha in the last 35 years. This shows that there are serious changes in the agricultural crop production pattern of the study area. The result is consistent with crop production in Gaziantep province. A comparison of the dry farm and horticultural crops between 2002 and 2016 in the province clearly show a sharp decline in the dry farm products and dramatic increase in horticultural products such as pistachio (Fig. 5). The result indicates that the change is prevalent in the region beyond the district.

Table 3. Areal distribution of agricultural land use in the study area [ha]

\begin{tabular}{|l|c|c|c||}
\hline \multicolumn{1}{|c|}{ Land use / cover } & 2019 & 2000 & 1984 \\
\hline \hline Dry farming & 7217.37 & 9990.81 & 11019.51 \\
\hline Irrigated farming & 4867.02 & 5617.62 & 4199.83 \\
\hline Horticultural crops & 8861.49 & 7850.25 & 5932.08 \\
\hline Grassland & 3645.18 & 1475.64 & 3942.45 \\
\hline Settlement & 1293.48 & 950.22 & 790.67 \\
\hline Total area & 25884.54 & 25884.54 & 25884.54 \\
\hline
\end{tabular}

The interactions between climate and land use change is complex and human activities have been the primary source of land use change. Agricultural, urbanization and other infrastructure developmental activities are leading to climate change but, on the other hand, it is an important factor for land use change as it impacts on the terrestrial, hydrological and climatic regimes. In our study area the increase in temperature over the past three decades (Fig. 3) might have caused farmers to shift from customary farming practice to horticultural farming, which has a higher economic return. The long-term effects of climate change are expected to increase heat waves and heavy precipitation, and decreased water resources in semi-arid regions. High temperature affects vegetation cover as well as the amount of water needed for irrigation.

As of the year 2019, water irrigated 4,867 ha agricultural area has not changed much. From the year 1984 to 2000, irrigated agricultural area increased to 5,617 ha. However, after 2010, the irrigated area decreased to the level of 1984. Furthermore, the irrigated agricultural area, which was around $16 \%$ of the area of the Araban district in 1984, is today around $18 \%$. This is an indication that there is a change in irrigated agricultural land over the last 35 years. Irrigated agricultural land has high potential for altering the climate. Irrigated land is extensive in semi-arid areas, with the study area also showing a slight increase in irrigated area, which is an indication 
of a lack of reliable rainfall (Fig. 4). Irrigation agricultural land could contribute to climate change by increasing transpiration and evaporation, and enabling higher leaf areas.

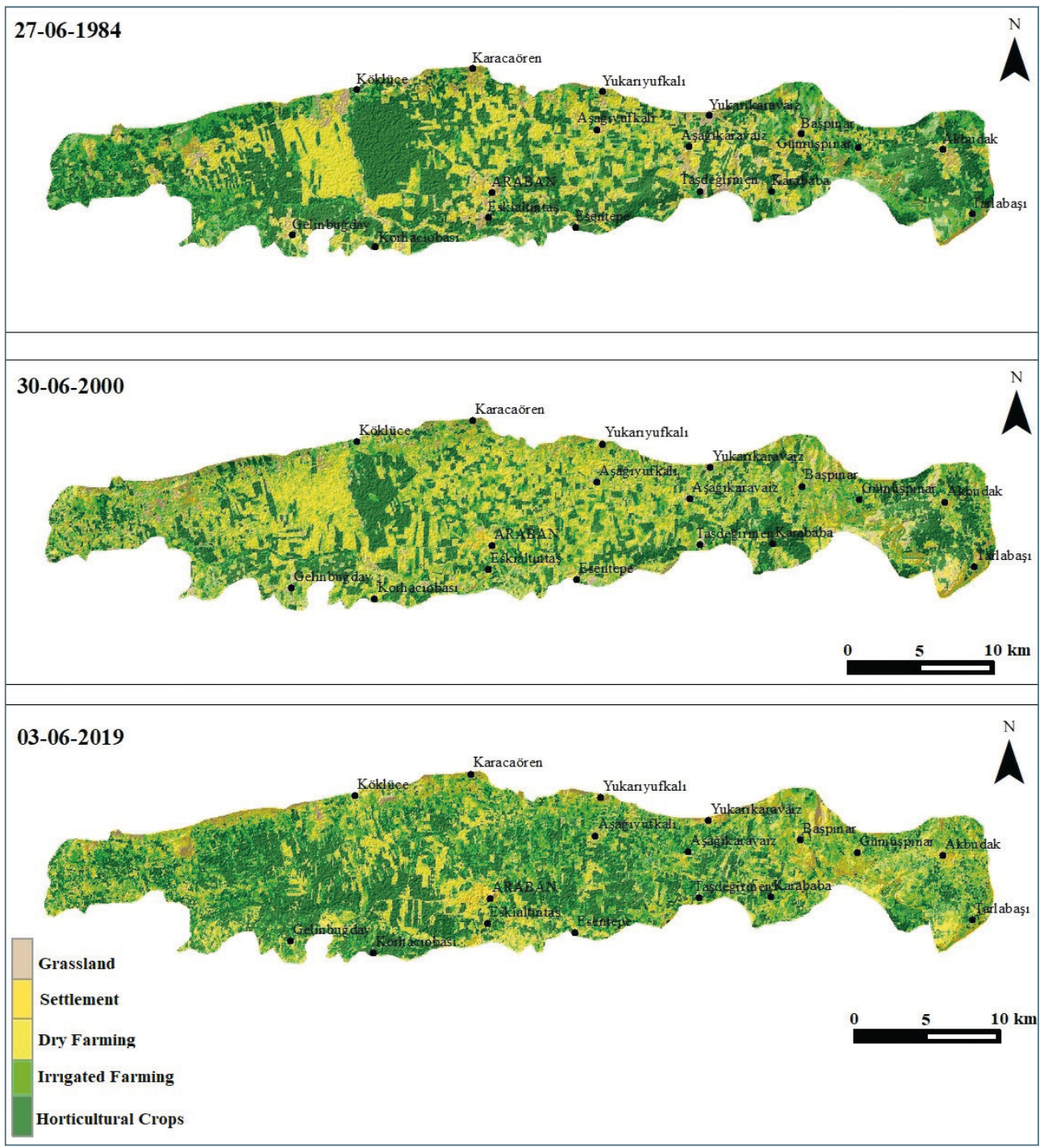

Fig. 6. Agricultural land use change of study area 1984-2019

Source: Landsat USGS

The decrease in dry farming activities coupled with increase in irrigation farming in a study area which has a semi-arid climate feature has the potential to cause ecological problems in the future. These risks include such as the rapid drop 
of groundwater level, drying of wetlands and the disappearance of the diversity of living things in these wetland environments. In southeastern Anatolia, where the Araban Plain is located, underground water resources are in the phase of exhaustion at the moment. The disappearance of dry farming activities will lead to the depletion of underground water resources and the formation of sinkholes. At the same time, dry agricultural activities in the study area may return again as a result of the consumption of water resources in the coming years.

\section{Conclusions}

In this study, the spatial and temporal change of agricultural land use in the Araban district between 1984 and 2019 was analyzed with the help of Remote Sensing and Geographic Information Systems. Landsat data was used in the research. Using an unsupervised classification of Landsat satellite images, three main types of agricultural activities were identified, namely horticulture / garden crops, irrigated farming and dry farming activities. Over the last 35 years dry farming agricultural areas have dramatically decreased, horticultural / garden cultivation has increased significantly but there has only been a slight change in the amount of irrigated fields. The main reason for the decrease in dry agricultural fields was attributed to a preference of more profitable horticulture crops such as peanuts, grapes and olives over dry field products such as wheat and barley. Those changes are also consistent with the change in agricultural products in Gaziantep province, which showed a decrease in dry farming crops and an increase in horticultural crops. An increase in irrigation farming, coupled with a decrease in dry-farming, could be an indication of the lack of reliable rainfall and the depletion of ground water. Following the depletion of ground water, dry farming might also start to increase over time; however, any increase in population and settlement coupled with inconsistent rainfall could cause a serious threat for food security. In order to predict the consequences, the changes in climate and land use, together with a consistent inventory of local and regional cultivated crops, should be conducted.

Moreover, land cover change in the study area, together with the reduction of green areas and dry agricultural areas, the expansion of settlement areas and the introduction of agricultural products that demand more water have also been identified. These environmental problems, which are accompanied by increasing population growth, are a growing problem beyond the Araban district. Therefore, necessary measures should be taken to put an end to this situation by local administrations and related institutions. Subsequently, an environmentally friendly, sustainable agriculture and settlement plan needs to be prepared and implemented. 


\section{References}

[1] UN: The state of food security and nutrition in the world 2019: safeguarding against economic slowdowns and downturns. 2019.

[2] Vermeulen S., Aggarwal P.K., Ainslie A., Angelone C., Campbell B.M., Challinor A.J. et al.: Options for support to agriculture and food security under climate change. Environmental Science and Policy, vol. 15, 2012, pp. 136-144.

[3] Department of Economic and Social Affairs, U.N.: Growing at a slower pace. Department of Economic and Social Affairs, New York 2019.

[4] Sundarakumar K., Harika M., Begum S.A., Yamini S., Balakrishna K.: Land use and land cover change detection and urban sprawl analysis of Vijayawada city using multitemporal landsat data. International Journal of Engineering Science and Technology, vol. 4(01), 2012, pp. 170-178.

[5] Debnath J., Das N., Ahmed I., Bhowmik M.: Chronological change of land usel land cover of the Muhuri River Basin from 1972 to 2016, Tripura, North-East India. Indian Journal of Science and Technology, vol. 10, 2017, pp. 1-18.

[6] Geist H.J., Lambin E.F.: Proximate causes and underlying driving forces of tropical deforestation. Bioscience, vol. 52, 2002, pp. 143-150.

[7] Lakshumanan C., Pradeep Kishore V., Viveganandan S., Krishnakumar P., Muthusankar G.: Landuse/land cover dynamics study in Nilgiris district part of Western Ghats, Tamilnadu. International Journal of Geomatics and Geosciences, vol. 2, no. 3, 2012, pp. 911-923.

[8] Dubovyk O. The role of Remote Sensing in land degradation assessments: opportunities and challenges. European Journal of Remote Sensing, vol. 50, 2017, pp. 601-613.

[9] Pawe C.K., Saikia A.: Unplanned urban growth: land use/land cover change in the Guwahati Metropolitan Area, India. Geografisk Tidsskrift-Danish Journal of Geography, vol. 118, 2018, pp. 88-100.

[10] Polasky S., Nelson E., Pennington D., Johnson K.A.: The impact of land-use change on ecosystem services, biodiversity and returns to landowners: a case study in the state of Minnesota. Environmental and Resource Economics, vol. 48, 2011, pp. 219-242.

[11] Chowdhury M., Hasan M.E., Abdullah-Al-Mamun M.M.: Land use/land cover change assessment of Halda watershed using remote sensing and GIS. The Egyptian Journal of Remote Sensing and Space Science, vol. 23(1), 2020, pp. 63-75.

[12] Shalaby A., Tateishi R.: Remote sensing and GIS for mapping and monitoring land cover and land-use changes in the Northwestern coastal zone of Egypt. Applied Geography, vol. 27(1), 2007, pp. 28-41.

[13] Mulla D.J.: Twenty five years of remote sensing in precision agriculture: Key advances and remaining knowledge gaps. Biosystems Engineering, vol. 114(4), 2013, pp. 358-371. 
[14] Dewan A.M., Yamaguchi Y.: Land use and land cover change in Greater Dhaka, Bangladesh: using remote sensing to promote sustainable urbanization. Applied Geography, vol. 29, 2009, pp. 390-401.

[15] Cegielska K., Noszczyk T., Kukulska A., Szylar M., Hernik J., Dixon-Gough R., Jombach S., Valánszki I., Kovács K.F.: Land use and land cover changes in post-socialist countries: Some observations from Hungary and Poland. Land Use Policy, vol. 78, 2018, pp. 1-18.

[16] Sharma L., Pandey P.C., Nathawat M.S.: Assessment of land consumption rate with urban dynamics change using geospatial techniques. Journal of Land Use Science, vol. 7(2), 2012, pp. 135-148.

[17] Mishra P.K., Rai A., Rai S.C.: Land use and land cover change detection using geospatial techniques in the Sikkim Himalaya, India. Egyptian Journal of Remote Sensing and Space Science, vol. 23(2), 2019, pp. 133-143.

[18] Dannenberg P., Kuemmerle T.: Farm size and land use pattern changes in postsocialist Poland. The Professional Geographer, vol. 62(2), 2010, pp. 197-210.

[19] Yan H., Liu J., Huang H.Q., Tao B., Cao M.: Assessing the consequence of land use change on agricultural productivity in China. Global and Planetary Change, vol. 67(1-2), 2009, pp. 13-19.

[20] Wan N.: Pesticides exposure modeling based on GIS and remote sensing land use data. Applied Geography, vol. 56, 2015, pp. 99-106.

[21] Tunç E., Özkan A., Çelik M.A.: Determination of the K-factor of Arable Land in Yavuzeli and Araban / Gaziantep Province. Journal of International Social Research, vol. 6(28), 2013, pp. 432-440.

[22] Tunç E., Celik M.A., Gulersoy A.E.: Investigation of the phenology of Pistachio (Pistacia vera L.) on different soil types using MODIS NDVI data. Geography, vol. 2(12), 2013, pp. 231-237.

[23] Tunç E., Çelik M.A.: Monitoring the effects of rainfall conditions on wheat (Triticum Aestivum L.) fields using MODIS data in Araban / Gaziantep, Turkey. Fresenius Environmental Bulletin, vol. 23(3), 2014, pp. 728-737.

[24] Kottek M., Grieser J., Beck C., Rudolf B., Rubel F.: World map of the Köppen-Geiger climate classification updated. Meteorologische Zeitschrift, vol. 15(3), 2006, pp. 259-263.

[25] Bricklemyer R.S., Lawrence R.L., Miller P.R., Battogtokh N.: Predicting tillage practices and agricultural soil disturbance in north central Montana with Landsat imagery. Agriculture, Ecosystems and Environment, vol. 114(2-4), 2006, pp. 210-216.

[26] Pantaleoni E., Engel BA, Johannsen C.J.: Identifying agricultural flood damage using Landsat imagery. Precision Agriculture, vol. 8(1-2), 2007, pp. 27-36.

[27] Leslie C.R., Serbina L.O., Miller H.M.: Landsat and agriculture - case studies on the uses and benefits of Landsat imagery in agricultural monitoring and production. U.S. Geological Survey Open-File Report, 1034, 2017. 
[28] Chen Y., Lu D., Luo L., Pokhrel Y., Deb K., Huang J., Ran Y.: Detecting irrigation extent, frequency, and timing in a heterogeneous arid agricultural region using MODIS time series, Landsat imagery, and ancillary data. Remote Sensing of Environment, vol. 204, 2018, pp. 197-211.

[29] Cohen J.: A coefficient of agreement for nominal scales. Educational and Psychological Measurement, vol. 20, no. 1, 1960, pp. 37-46.

[30] Gaziantep Provincial Directorate of Agriculture and Forestry. 2018. Gaziantep İl Tarım ve Orman Müdürlügü. https://gaziantep.tarimorman.gov.tr/ Belgeler/Brifing\%202018.pdf [access: 18.07.2020]. 